\title{
Sosyo
}

Ekonomi

\section{Konut Sektöründe Kapitalizasyon Oranlarını Belirleyen Faktörler: Türkiye İçin Bir Mikro-Veri Analizi}

\author{
Abuzer PINAR
}

Murat DEMIR

abuzer.pinar@harran.edu.tr

mdemir@harran.edu.tr

\section{The Determinants of Capitalization Rates in Housing Sector: A Micro- Data Analysis of Turkey}

\begin{abstract}
The capitalization rate is important in demand for houses either for dwelling or for an alternative financial investment. A portfolio holder may buy a house to live in or to maintain the value of his/her financial saving. On the other hand, one may prefer a mortgage loan to buy a house to live in, instead of paying rent. A rationale for such behaviors is the capitalization rate. In this study, we utilize a set of micro-data collected from the various advertising sources open to public, and compute capitalization rates, and then estimate those rates on a set of variables related to house characteristics. Our findings show that the capitalization rates are higher for second hand houses, probably because of higher maintenance expenses. Also the size, the distance to city center, and some other factors seem to significantly affect the capitalization rates.
\end{abstract}

Keywords

: Capitalization Rate, Demand for Housing, Regression.

JEL Classification Codes : $\quad$ C80, R21, R31.

\section{Özet}

Konut sektöründe kapitalizasyon oranları, barınma ihtiyacı ve bir yatırım aracı olarak kullanılan konut üretimi ve talebi açısından önem arz etmektedir. Finansal sermayeye sahip bir iktisadi karar alıcının barınma ihtiyacını gidermek veya sahip olduğu parasal tasarrufun değerini korumak üzere konut satın alması mümkün olabileceği gibi, konut kiralamak yerine kredi kullanarak konut satın alması da yaygın bir davranıştır. Bu çerçevede iktisadi karar alıcılar açısından hangi davranışın rasyonel olduğunu saptamanın yöntemlerinden birisi kapitalizasyon oranıdır. Bu çalışmada, kamuya açık ilanlardan derlenen verilerle Türkiye'de kapitalizasyon oranları hesaplanmış ve konutların özelliklerinden oluşan bir değişken seti ile tahmin yapılmıştır. Bulgulara göre ikinci el konutların kapitalizasyon oranları yeni konutların kapitalizasyon oranlarından daha yüksek çıkmaktadır. Konutların büyüklüğü, merkeze yakınlığı ve diğer bazı faktörlerin de kapitalizasyon oranları üzerinde etkisi anlamlı bulunmuştur. 
Abuzer PINAR \& Murat DEMIR 


\section{Giriş}

Ekonomik gelişme ile paralel hareket eden sektörlerden birisi konut sektörüdür. Gelişmiş ve gelişmekte olan ekonomilerde büyümeye öncülük eden bu sektör, diğer yandan daralma dönemlerinde çöküşün tetikleyicisi olabilmektedir. 2008 yılında ortaya çıkan küresel krizin türev araçlar üzerinden olsa bile, büyük ölçüde konut sektöründen kaynaklandığı düşünüldüğünde, söz konusu sektörün işleyişinin ciddiye alınması gerektiği açıktır (IMF, 2004). Kriz ile başlayan konjonktürde emlak sektöründe bir gevşeme olmakla beraber, birkaç nedenle önümüzdeki yıllarda konut önemli bir sektör olmaya devam edecektir. Nüfus artışı yanında, kentleşme, kalitesiz konutların ve gecekondu bölgelerinde sürmekte olan kentsel dönüşüm projeleri, mortgage piyasasında beklenen gelişmeler, ulusal ve uluslararası düzeyde büyüyen şirketlerin ofis ihtiyacı bu nedenler arasında sayılabilir (Deloitte, 2010: 5).

Gelişmiş veya gelişmekte olan ülkeler olsun, konut barınma veya servet biriktirme açısından vazgeçilmez bir araçtır. Temel ihtiyaçlardan birisi olan barınma ihtiyacı konutun satın alınması veya kiralanması yoluyla giderilebilir. Mülkiyet edinilerek bu ihtiyacın giderilmesi dışsal bir davranış olarak da ortaya çıkabilir. Ancak iktisadi açıdan bakıldığında, barınma amaçı da satın alınsa, kiralama yoluyla da ihtiyacın giderilmesi mümkün olduğundan ve konut alternatif bir servet biriktirme aracı olduğundan, konutun uzun dönem net değeri ve nakit getirisi önem kazanmaktadır. Uzun dönem değeri ve nakit getirisi ise kapitalizasyon (sermayeleştirme) kavramını önemli hale getirmektedir.

Çalışmalar, konut büyüklüğüne olan talebin gelir esnekliğinin düşük olduğunu göstermektedir. Fiyat esnekliği daha yüksek olmakla beraber, daha geniş bir aralıkta ortaya çıkmakta ve büyüklükten ziyade alanın kullanımı daha etkili olmaktadır. Ulaşım ve komşuluk niteliğinin de konut talebi üzerinde etkili olduğu görülmektedir. Bazı çalışmalar, ek 10 metrekareye ödenmek istenen fiyatın gelire oranını test etmekte ve \%3-9 arası bir oran bulunmaktadır (Follain ve Jimenez, 1985). Sun $v d$. (2010) ise yaptıkları çalışmada, konut tercihinin konutun birim özellikleri, kira ve fiyatlardan ziyade komşuluk/çevresel özelliklerine daha duyarlı olduğunu göstermektedir.

Türkiye'de konuya ilişkin çalışmalar sınırlı düzeydedir. Yapılan makro düzeydeki bazı çalışmalar (Berberoğlu, 2009; Öztürk ve Fitöz, 2009; Bekmez ve Özpolat, 2013) ve çok az sayıdaki mikro çalışmalar (örnek bir çalışma için bkz. Özsoy ve Şahin, 2008) dışında bazı konut projeleri için hazırlanan konut değerleme raporları mevcuttur. Konut projelerinde, Sermaye Piyasası Kurulu Mevzuatı gereği, gayrimenkul değerleme raporları hazırlanmaktadır (örnek çalışmalar için bkz. Akmerkez GYO, 2011; Emlak Konut GYO, 2014). Bu raporlarda konut projelerinin konumu ve çevresel özellikleri, ulaşım imkanları, tapu, kadastro ve imar bilgileri, yapısal ve teknik özellikler dikkate alınmaktadır. Konutun birim değeri ise veri koşullarda metrekare büyüklüğü, oda sayısı ve diğer özellikleri ile belirlenmektedir. Büyüme potansiyeli yüksek olan ve her genişleme döneminde büyüme içerisinde dikkate değer bir paya sahip olan konut sektöründe fiyatları, getirileri ve 
kapitalizasyon oranlarını belirleyen faktörlerin değerlendirilmesi önem kazanmaktadır. Bazen gayrimenkule yapılacak yatırımın getirisi belirlenirken, bazen de emsal getirilere göre hesaplanan kapitalizasyon oranları doğrultusunda muadil gayrimenkullerin değeri hesaplanmaktadır (Emlak Konut GYO, 2012).

$\mathrm{Bu}$ makalede, kamuya açık ilanlardan derlenen veriler kullanılarak, konut özelliklerinin kapitalizasyon oranı üzerindeki etkisi tahmin edilmektedir. Birinci bölümde, konut sektöründe kapitalizasyon oranının önemi ve uygulamaya ilişkin tartışmalar yer almaktadır. İkinci bölümde verilerin niteliği, kapitalizasyon oranı hesaplamaları ve bu oranı belirleyen değişkenler test edilmektedir. Konuya ilişkin tartı̧̧malar son bölümde yer almaktadır.

\section{Teorik Çerçeve ve Literatür Özeti}

Konut iki temel nedenle talep edilebilir. Bir neden barınma amaçlıdır. Diğer neden ise parasal tasarrufların değerlendirilmesi amacıyla olabilir. Barınma amaçlı satın alınan konutun nakit veya mortgage kredisi olmak üzere iki finansman yöntemi vardır. Nakit olarak alınması halinde, mülkiyete ödenen para miktarının getirisi ile konutun ev sahibi açısından ortaya çıkan emsal kira bedeli ve konutun zaman içerisinde kazanacağı değerin karşılaştırılması gerekir. Örneğin, bir karar alıcı kirada oturarak konuta ödeyeceği para miktarını alternatif araçlarla değerlendirmek isteyebilir. Belirli bir zaman aralığında elde edeceği kazanç, konutun sermaye kazancı ve kirası toplamından yüksekse kirada oturması daha rasyonel olacaktır. Barınma amaçlı satın alınan konuta ilişkin farklı bir davranış, kirada oturmak yerine mortgage kredisi ile konut satın alınması ve kira ödemek yerine belirli bir süre içerisinde kendi evine sahip olmak olabilir. Bu durumda ise kredi dolayısıyla ödenen taksit toplamları ve emsal kira bedeli toplamının, konutun kredi ödemesi bitimindeki değerinden daha düşük olması gerekir.

Yatırım amaçlı konut satın alınması halinde ise konutun fiyatındaki artı̧̧ ile kira getirisinin toplamının alternatif getirilere göre daha cazip olması beklenir. Benzer şekilde yatırım amaçlı ve mortgage kredisi ile satın alınan bir konut için yapılan kredi ödemesi toplamının konutun fiyat artışı nedeniyle ortaya çıkan değer artış kazancının maliyetinden yüksek olması gerekir. Aksi durumda konutun yatırım amaçlı olarak alınması ekonomik olmayacaktır. Mortgage sisteminin beklentileri karşılayacak bir yapıda işleyebilmesinde ekonomik istikrarın ve düşük faiz oranlarının temel belirleyici olduğu, bunların olmadığı bir yapıda söz konusun sistemin tek başına yeterli olamayacağı söylenebilir (Berberoğlu, 2009).

Bütün bunların yanında, karar birimlerinin risk algılamasının da hesaba katılması gerekir. Kazancı daha düşük görünse bile konutun daha güvenli liman olarak görülmesi alternatif yatırım araçlarına göre tercih nedeni olabilir. Türkiye'de konut arz ve talebinin belirleyicilerinin ne olduğu ve konut piyasasında bir fiyat balonunun bulunup bulunmadığına yönelik ampirik bir çalışma yapan Öztürk ve Fitöz (2009), konut fiyatları ile konut talebi arasında pozitif bir ilişki bulmuştur. Teorik çerçeveye çok da uygun olmayan 
böylesi bir sonucun ortaya çıkışında enflasyonist ortamlarda insanların konut yatırımını enflasyona karşı korunmanın yollarından birisi olarak görmesi belirtilebilir. İlgili çalışmada kişi başına düşen gelir düzeyi ile konut talebi, ekonomideki likidite genişlemesi ile konut arzı, kişi başına düşen gelir düzeyi ile konut arzı, konut fiyatları ile konut arzı arasında da pozitif yönlü ilişkilerin var olduğu saptanmıştır. Enflasyon oranı ile konut talebi arasındaki pozitif ilişki de bazen konutun enflasyona karşı bir güven aracı olarak kabul edildiği biçiminde değerlendirilmektedir (Bekmez ve Özpolat, 2013).

Kapitalizasyon oranlarının belirlenmesinde etkili olan dinamiklerden birisi piyasanın genel durumu ve ilgili yatırımcıların davranışlarıdır. Yatırımcı gayrimenkul yatırımının geri dönüşü ile kira geliri beklentilerini değerlendirir. Gayrimenkul değerinin yüksek ancak beklenen kira gelirinin düşük olduğu durumlarda yatırımcılar gayrimenkulü yüksek bir kapitalizasyon oranı ile değerlerler. Bu noktada gayrimenkul piyasasındaki türlü tercihlere kapitalizasyon oranları aracılığıyla da yön verilebileceğini söylemek mümkündür (An ve Deng, 2009).

Kapitalizasyon oranı üzerinde gayrimenkulün niteliği ile birlikte konjonktürel yapı ve gayrimenkulün finansman koşullarının belirleyici olduğu söylenebilir. Stockholm'de yapılan bir saha çalışmasında kapitalizasyon oranları üzerinde konut finansman olanaklarının da etkili olduğu sonucu elde edilmiştir. Aynı çalışmada elde edilen bir başka bulgu ise, işyeri olarak kullanılacak yerlere ilişkin kapitalizasyon oranlarının konut olarak kullanılacak gayrimenkullere göre daha yüksek kapitalizasyon oranlarına sahip olduğudur (Hendershott ve Turner, 1999). Eko belgeli konut ve ofislerin de kapitalizasyon oranlarının yüksek olduğu sonucu elde edilmiştir (McGrath, 2013). Özellikle enerji fiyatlarının yüksek olduğu enerjide dışa bağımlı ülkelerde çevreye duyarlı yüksek enerji verimliliğine sahip eko belgeli konut ve ofislerin getirileri diğerlerine göre daha yüksek olmaktadır.

ABD için yapılan bir çalışmada, konut fiyatlarının ailelerin çocuk sahibi olma konusundaki kararlarını nasıl etkiledikleri incelenmektedir. Konut fiyatlarında kısa dönemli artışlar hiç evi olmayan ailelerin çocuk sahibi olma düşüncelerini olumsuz etkilerken, ev fiyatlarındaki artışlar konut sahibi olanların çocuk sahibi olma konusundaki kararlarını ise olumlu etkilemektedir. Konut fiyatlarındaki 10.000.- dolarlık bir artış konut sahibi olmayanların çocuk sahibi olma konusundaki kararlarını \%2,4 olumsuz etkilerken $(\% 2,4$ azaltmaktadır) konut sahibi olanların çocuk sahibi olma konusundaki kararlarını $\% 5$ olumlu etkilemektedir. (\%5 artırmaktadır). ABD'de bu bağlamda konut fiyatlarındaki 10.000.dolarlık bir artışın ortaya çıkardığı net etkinin ailelerin çocuk sahibi olma konusundaki kararlarını \%0,8 artırdığı sonucu elde edilmiştir. Burada şunu söylemek gerekir konut fiyatlarındaki artışa gösterilen tepki ve net etki ilgili konutların bulunduğu bölgenin demografik özelliklerine göre değişmektedir (Dettling ve Kearney, 2013).

Froland (1987) kapitalizasyon oranını ipotekli konut kredi sözleşmelerindeki oranın bir fonksiyonu olarak kabul etmiştir. Hazine bonolarının yıllık getirileri, hisse senedi 
getirileri gibi değişkenler kapitalizasyon oranı belirlenirken takip edilen, karşılaştırmalar yapılan değişkenler olarak ele alınabilir. Ancak Froland kapitalizasyon oranları üzerinde çalışırken gayrimenkul türüne göre bir değerlendirme yapmamıştır. Kapitalizasyon oranlarının zaman içinde değişebileceğine de herhangi bir vurgu yapılmamıştır.

Evans (1990) gayrimenkul değerinde meydana gelen değişimle makroekonomik göstergeler ve borsadaki değişimler arasındaki ilişkiye yoğunlaşmış gayrimenkul sektörünün makroekonomik göstergelerdeki değişim ile borsa göstergelerindeki değişimlere bir çeyreklik bir gecikme ile tepki verdiğini ortaya koymuştur. Liu $v d$. (1990) de kapitalizasyon oranını ticari emlak fiyatlarını hesaplamak için de kullanmışlardır. Burada amaç gayrimenkul sektörünün borsa ile ne derece entegre olduğunu ve senkronize çalıştığını görebilmek maksadıyla araştırma yapmaktır. Elde edilen bulgular sermaye piyasaları ile gayrimenkul sektörü arasındaki ilişkinin çok da birbirine bağlı olarak yürümediği şeklindedir. Jud ve Winkler (1995) ise kapitalizasyon oranlarının sermaye piyasalarıyla güçlü bir biçimde ilişki halinde olduğunu vurgulamaktadırlar. Bu ilişki, yani sermaye piyasalarındaki gelişmelerin gayrimenkul sektörüne ve dolayısıyla kapitalizasyon oranına yansıması, belirli bir gecikme ile ve piyasanın büyüklüğüne göre şekil almaktadır.

Ambrose ve Nourse (1993) kapitalizasyon oranlarının belirlenmesinde gayrimenkul türündeki farklılıkların önemli olduğunu vurgulamaktadırlar. Ancak lokasyon farklılıklarının (sadece 4 bölgeyi incelemişlerdir) kapitalizasyon oranı üzerinde fazla bir etkisinin olmadığını belirtmektedirler. Burada gayrimenkulün türüne göre bir kapitalizasyon oranı sıralaması yapılmış, en yüksek değerden en küçük değere doğru kapitalizasyon oranı sıralamasında ilk sırada otellerin yer aldığı, sonrasında motellerin, sanayi yapılarının, büyük alışveriş merkezlerinin, ofislerin ve dairelerin yer aldığı görülmüştür. Bu çalışmada elde edilen bir diğer bulgu beklenen enflasyon oranı ile kapitalizasyon oranı arasında pozitif bir ilişkinin bulunduğudur.

Diğer yandan Chay ve Greenstone (1998) hava kirliliği konusunda duyarlılığı olan ve olmayan ülke grupları arasında karşılaştırma yaparak bazı analizler yapmaktadır. Çalışmalarında, hava kirliliği konusunda duyarlılığı olan ve ona göre konut politikaları üreten ve düzenleyici, denetleyici tedbirler uygulamayan ülkelerde konutların daha yüksek değerlere sahip olduğunu ve dolayısıyla konut sahiplerinin daha yüksek getiriler elde ettikleri sonucuna varmışlardır. Çalışmada hava kirliliğine neden olan partikül maddelerdeki bir birimlik azalmanın ilgili ülkede konut değerlerini \%0,7 ile \%1,5 arasında arttırdığ sonucu elde edilmiştir. İstanbul'da konut değerini belirleyen 31 değişken üzerinden yapılan bir çalışmada ise en büyük etkiye sahip 5 değişken ortaya çıkmıştır. Bunlar konutun büyüklügü ve konumu, güvenlik durumu, asansörün varlığı ve merkezi 1sıtmaya sahip olup olmadığıdır (Özsoy ve Şahin, 2008).

Makro düzeyde yapılan ve büyük ölçüde zaman serilerine dayanan çalışmalarda konut sektöründeki fiyat dalgalanmaları diğer makro değişkenlerle ilişkilendirilmektedir. $\mathrm{Bu}$ çalışmalarda konjonktürel dalgalanmaların ve alternatif araçların fiyatlarındaki 
dalgalanmaların etkisi açıç̧a görülmektedir. Konuya ilişkin diğer önemli bir soru, konutun özelliklerinin konut değerine etkisidir. Diğer deyişle konjonktürel dalgalanmalardan bağımsız olarak barınma veya yatırım amaçlı talep edilen konutların değeri üzerinde belirleyici olan konut özelliklerinin etkisidir. Konuya ilişkin geniş bir literatür değerlendirmesi yapan Follain ve Jimenez (1985), çalışmaların tamamına yakınında konut büyüklüğüne olan talebin gelir esnekliğinin düşük olduğunu kaydetmektedir. Aynı çalışmalarda fiyat esnekliği daha yüksek olmakla beraber, daha geniş bir aralıkta ortaya çıkmakta ve büyüklükten ziyade alanın kullanımı daha etkili olmaktadır. Ayrıca, ulaşım imkanları ve komşuluk niteliklerinin de konut talebi üzerinde etkili olduğu ortaya çıkmaktadır. Konutun büyüklüğünün öne çıktığı bazı çalışmalar, ek 10 metrekareye ödenmek istenen fiyatın gelire oranını test etmekte ve \%3-9 arası bir orana ulaşmaktadır. Sun $v d$. (2010) ise yaptıkları çalışmada metro yapının konut değerleri üzerindeki etkisini araştırmaktadır. Çalışmada ulaşılan sonuçlara göre, konut tercihinin konutun birim özellikleri, kira ve fiyatlardan ziyade komşuluk/çevresel özelliklerine daha duyarlı olduğu ortaya çıkmaktadır.

Ele alınması gereken konulardan birisi sektördeki kapitalizasyon oranları ve bu oranları belirleyen faktörlerdir. Barınma veya yatırım amaçlı olsun, her iki durumda da konutun satın alındığı andaki değeri ve getiri önemlidir. Para ve sermaye piyasalarının yeterince gelişip kurumsallaşamadığı gelişmekte olan ülkelerde gayrimenkul yatırımları hanehalkı açısından tasarrufların değerlendirildiği önemli yatırım araçlarından birisidir (Ayan, 2010). Gayrimenkul değerinin belirlenmesi, gelişmiş ülkelerde üzerinde önemle durulan ve sürekli gelişim gösteren bir alandır. Gayrimenkul değerlerinin belirlenmesi birçok açıdan önemli olmakla beraber, özellikle konut talep eden kesimler açısından davranışları etkileyebilecek niteliktedir.

\section{Veri ve Yöntem}

Bir gayrimenkulün kapitalizasyon oranı aşağıdaki şekilde hesaplanabilir:

\section{Kapitalizasyon Oranı=Ylllık Net Getiri / Satış Fiyatı}

$\mathrm{Bu}$ oran, bir gayrimenkulden elde edilen ylllk net getiri ile söz konusu gayrimenkulün değeri arasındaki ilişkiyi göstermektedir. Gayrimenkulün değerinin belirlenmesi söz konusu olduğunda, yıllık net getirinin uygun kapitalizasyon oranına bölünmesi gerekir.

Gayrimenkulün konumu ve sahip olduğu nitelikleri, ilgili gayrimenkulün değerinin tespitinde doğrudan belirleyici olan değişkenlerdir. Gayrimenkulün sahip olduğu nitelikleri içeren değişkenler gayrimenkulün değerini etkileyen içsel unsurlar olarak ele alınırken doğrudan gayrimenkule ait olmayan gayrimenkul dışındaki farklı sebepler gayrimenkulün değerini etkileyen dışsal unsurlar olarak ele alınmaktadır. Gayrimenkulün 
konumu, binanın yaşı, mimarisi, altyapı imkânları, kullanılan malzeme ve işçilik gibi unsurlar gayrimenkulün değeri konusunda bilgi veren teknik ve fiziki koşullardır.

Gayrimenkulün değerini etkileyen dışsal (doğrudan gayrimenkule ait olmayan) unsurlar ekonomik, sosyo-kültürel ve yasal mevzuat şeklinde özetlenebilir. Ekonomik unsurlar gayrimenkulün getirisi, piyasadaki cari faiz oranı, piyasadaki kredi hacmi, kredi maliyetleri, mevcut arazi ve bina stokları, ekonomik yapının genel durumu gibi faktörlerden oluşmaktadır. Çevre, demografi, ulaşım sorunları, yerleşim alanındaki istihdam olanakları gibi etkenler de sosyo-kültürel unsurları oluşturmaktadır. Yasal mevzuat ise genel olarak gayrimenkulün değerini etkileyebilecek olan tapu ve kadastro mevzuat1, kent planı, gayrimenkule bağlı haklar ve arsa veya binanın değerini değiştirebilecek düzenlemeleri kapsamaktadır (McGreal ve Taltavull de La Paz, 2012; Altınırmak vd. 2013).

$\mathrm{Bu}$ çalışmada kullanılan veriler 2013 yılının son çeyreğinde kamuya açık satış ilanlarından derlenmiştir. Örneklem 1784 'tür. Veri derlemede daha fazla sayıda ilana rastlandığı halde elemeler yapılmıştır. Öncelikle kapitalizasyon oranının hesaplanması için hem konutun piyasa değeri, hem de nakit getirisi olan kirasının bilinmesi gerekmektedir. $\mathrm{Bu}$ yüzden ilanda kira bilgisi mevcut olmayanlar örneklemden çıkarılmıştır. Kullanılan veri say1s1 1730 'dur.

Belirtilmesi gereken diğer bir konu, konut fiyatları ve kiraların mülkiyet sahiplerinin talep ettiği fiyatlar olduğudur. Alış-verişin belirli bir pazarlık fiyatı üzerinden gerçekleştiği düşünülebilir. Diğer yandan talep edilen fiyatların yukarı yönlü sapmalı olduğu düşünülse bile, talep edilen kira bedellerinin de benzer bir sapma içerdiğini, dolayısıyla kapitalizasyon oranlarının gerçekçi olduğu savunulabilir.

Elde dilen verilerde çok sayıda müstakil evin olduğu gözlenmiştir. Ancak yapılan betimsel analizlerde hem fiyat hem de kira açısından yüksek farklar ortaya çıkmıştır. Yapılan daha detaylı incelemelerde bu müstakil evlerin bir bölümünün çok yüksek piyasa değeri ve kiraya sahip olan yazlık veya villa türü lüks konutlar olduğu, diğer bir bölümünün ise tersine çok düşük piyasa değeri ve kiraya sahip olan gecekondu olduğu gözlenmiştir. Bu yüzden örneklemden bu veriler ayıklanarak sadece apartman dairesi analizlere katılmıştır. Tablo 1'de görüldüğü gibi örneklemde illerin önemli bir bölümü yer almaktadır (59 il merkezi). Örneklemde yer alan illerden İstanbul, Ankara ve İzmir'in payı yaklaşı olarak \%10 düzeyindedir (üç ilin toplamı payı yaklaşık olarak \%30'dur). Bu illeri \%7,4 ile Bursa ve farklı oranlarla Trabzon, Manisa, Malatya, Tekirdağ, Aydın, Antalya, Bilecik ve Mersin takip etmektedir. 
Tablo: 1

İler Bazında Verilerin Kapsamı

\begin{tabular}{|l|c|c|c|l|c|c|c|}
\hline İl Merkezi & Sayı & Yüzde & Kümülatif Yüzde & İl Merkezi & Sayı & Yüzde & Kümülatif Yüzde \\
\hline Adana & 28 & 1,6 & 1,6 & Karabük & 18 & 1,0 & 64,4 \\
\hline Adıaman & 5 & 0,3 & 1,9 & Kars & 5 & 0,3 & 64,7 \\
\hline Afyonkarahisar & 8 & 0,5 & 2,4 & Kastamonu & 16 & 0,9 & 65,6 \\
\hline Aksaray & 6 & 0,3 & 2,7 & Kayseri & 21 & 1,2 & 66,8 \\
\hline Amasya & 14 & 0,8 & 3,5 & Kırıkkale & 17 & 1,0 & 67,8 \\
\hline Ankara & 164 & 9,5 & 13,0 & Kırşehir & 20 & 1,2 & 69,0 \\
\hline Antalya & 43 & 2,5 & 15,5 & Kocaeli & 13 & 0,8 & 69,7 \\
\hline Artvin & 3 & 0,2 & 15,7 & Konya & 30 & 1,7 & 71,4 \\
\hline Aydın & 45 & 2,6 & 18,3 & Kütahya & 11 & 0,6 & 72,1 \\
\hline Balıkesir & 15 & 0,9 & 19,1 & Malatya & 59 & 3,4 & 75,5 \\
\hline Batman & 4 & 0,2 & 19,4 & Manisa & 51 & 2,9 & 78,4 \\
\hline Bayburt & 3 & 0,2 & 19,5 & Mersin & 41 & 2,4 & 80,8 \\
\hline Bilecik & 41 & 2,4 & 21,9 & Muğla & 33 & 1,9 & 82,7 \\
\hline Bolu & 15 & 0,9 & 22,8 & Muş & 1 & 0,1 & 82,8 \\
\hline Burdur & 11 & 0,6 & 23,4 & Nevşehir & 5 & 0,3 & 83,1 \\
\hline Bursa & 128 & 7,4 & 30,8 & Niğde & 16 & 0,9 & 84,0 \\
\hline Çanakkale & 10 & 0,6 & 31,4 & Ordu & 2 & 0,1 & 84,1 \\
\hline Denizli & 17 & 1,0 & 32,4 & Rize & 12 & 0,7 & 84,8 \\
\hline Diyarbakır & 20 & 1,2 & 33,5 & Sakarya & 25 & 1,4 & 86,2 \\
\hline Edirne & 16 & 0,9 & 34,5 & Samsun & 14 & 0,8 & 87,1 \\
\hline Elazığ & 12 & 0,7 & 35,1 & Sivas & 13 & 0,8 & 87,8 \\
\hline Erzincan & 5 & 0,3 & 35,4 & Şanlıurfa & 13 & 0,8 & 88,6 \\
\hline Erzurum & 3 & 0,2 & 35,6 & Tekirdağ & 47 & 2,7 & 91,3 \\
\hline Eskişehir & 16 & 0,9 & 36,5 & Tokat & 27 & 1,6 & 92,8 \\
\hline Gaziantep & 28 & 1,6 & 38,2 & Trabzon & 59 & 3,4 & 96,2 \\
\hline Hatay & 28 & 1,6 & 39,8 & Uşak & 5 & 0,3 & 96,5 \\
\hline Isparta & 24 & 1,4 & 41,2 & Van & 32 & 1,8 & 98,4 \\
\hline İstanbul & 181 & 10,5 & 51,6 & Yalova & 13 & 0,8 & 99,1 \\
\hline İzmir & 185 & 10,7 & 62,3 & Zonguldak & 15 & 0,9 & 100,0 \\
\hline Kahramanmaş & 18 & 1,0 & 63,4 & Toplam & $\mathbf{1 7 3 0}$ & $\mathbf{1 0 0 , 0}$ & \\
\hline
\end{tabular}

Tablo 2'de verilere ilişkin betimsel istatistikler verilmektedir. Buna göre Türkiye'de ortalama konut fiyatları 2013 yılı son çeyreği itibariyle 175.000.-TL'dir. Medyan değer ise 145.000.-TL'dir. Standart sapmadan görüldüğü gibi çok geniş yelpazede konut fiyatları mevcuttur. Ortalama aylık kira 756.-TL'dir. Aylık kiranın medyan değeri 650.TL'dir. Kapitalizasyon oranının aynı dönemdeki ortalama değeri 5,57, medyan değeri ise 5,33 'tür. 
Tablo: 2

Betimsel İstatistikler

\begin{tabular}{|l|r|r|r|r|r|}
\hline & Ortalama & Medyan & En Az & En Çok & Standart Sapma \\
\hline Piyasa Değeri & 175.000 & 145.000 & 30.000 & 1.290 .000 & 115.400 \\
\hline Kira & 756 & 650 & 150 & 4.000 & 428 \\
\hline Kapitalizasyon Oranı & 5,57 & 5,33 & 1,50 & 16,94 & 1,52 \\
\hline Büyüklük $\left(m^{2}\right)$ & 140,11 & 130 & 40 & 500 & 50,20 \\
\hline Oda Saylsl & 3,96 & 4 & 1 & 9 & 0,86 \\
\hline Binanın Yaşı & 7,54 & 4 & 0 & 50 & 8,49 \\
\hline Kat Saylsl & 5,76 & 5 & 2 & 31 & 3,01 \\
\hline
\end{tabular}

Yukarıda sözü edilen değerlere denk düşen konut özellikleri de aynı tabloda verilmektedir. Ortalama konut büyüklüğü $140 \mathrm{~m}^{2}$ civarındadır. Oda sayısı (salon dahil) ortalama ve medyan olarak 4 civarındadır. Dolayısıyla Türkiye'de ortalama "3 oda 1 salon" tipi konutlar yaygın olarak kullanılmaktadır. Ortalama bina yaşı 7,5 ve kat sayısı 5 civarındadır.

Tablo: 3

\section{Konutların Diğer Özellikleri}

\begin{tabular}{|l|c|c|}
\hline & Var & Yok \\
\hline Doğalgaz & 68,4 & 31,6 \\
\hline Asansor & 39,1 & 60,9 \\
\hline Kapalı Otopark & 41,9 & 58,1 \\
\hline Site İçinde & 23,9 & 76,1 \\
\hline Dış Isı Yalıtımı & 35,4 & 64,6 \\
\hline Merkeze Yakınlı & 40,7 & 59,3 \\
\hline Toplu Taşımaya Yakınlık & 49,6 & 50,4 \\
\hline
\end{tabular}

Konutların diğer özelliklerine bakıldığında (Tablo 3), konutların yaklaşık olarak \%68'inde doğalgaz kullanılmaktadır. \%39'u asansörlü, \%42 civarındaki bir bölümü kapalı otoparklı, \%24 civarındaki bir bölümü site içerisinde, $\% 35$ civarındaki bir bölümü 1sı diş 1sı yalıtımlıdır. Ayrıca \%40 civarındaki konutların şehir merkezine ve konutların yaklaşık yarısının toplu taşımaya yakın olduğu belirtilmiştir.

\section{Ampirik Bulgular}

Bu bölümde konut fiyatları, kiralar ve kapitalizasyon oranları konut özellikleri ile test edilmiştir. Kullanılan değişkenlerin bir bölümü konutun içsel özelliklerine ilişkindir. Oda sayısı, konutun büyüklüğü $\left(\mathrm{m}^{2}\right)$, binanın yaşı, 1sınma türü, asansör imkânı, kapalı oto parkı olup olmadığı, site içinde olup olmaması ve dış 1sı yalıtımı yanında, şehir merkezine yakın olup olmadığı ve topluma taşımaya uzaklığg değiş̧ken olarak kullanılmıştır. Bağımlı değişkenler fiyat ve kira doğal logaritma (ln) ve kapitalizasyon oranı düzey biçimindedir. 
Birinci sütunda gösterilen değerler fiyatların tahminidir. Oda sayısı, dış 1sı yalıtımı ve toplu taşımaya yakınlık konut fiyatlarında etkili olmazken, evin büyüklüğü, binanın yaşı, doğalgaz imkânı, asansör, kapalı otopark ve merkeze yakınlık konut fiyatlarını arttırmaktadır. Site içerisinde olması ise düşük düzeyde de olsa fiyatı düşürmektedir. Oda sayısının etkisiz olması konut büyüklüğü ile ilişkilidir. Sonuçlar, oda sayısından ziyade konut büyüklüğünün daha etkili olduğunu göstermektedir. Konut büyüklüğündeki $1 \mathrm{~m}^{2}$ 'lik artış fiyatlarda \%0,005'lik bir fiyat artışı anlamına gelmektedir. Örneğin, aynı özelliklere sahip $100 \mathrm{~m}^{2}$ 'lik bir evin fiyatı 100.000.-TL iken $150 \mathrm{~m}^{2}$ 'lik muadili 150.000.-TL'dir.

Tablo: 4

\section{Regresyon Sonuçları}

\begin{tabular}{|c|c|c|c|}
\hline Bağımlı Değişken & In(Fiyat) & $\ln$ (Kira) & Kapitalizasyon Oranı \\
\hline Sabit Terim & $\begin{array}{l}11,031 \text { **** } \\
(0,059)\end{array}$ & $\begin{array}{l}5,897 \text { **** } \\
(0,052)\end{array}$ & $\begin{array}{l}7,281 \text { **** } \\
(0,188)\end{array}$ \\
\hline Oda Saylsı & \begin{tabular}{|l|}
$-0,004$ \\
$(0,021)$
\end{tabular} & $\begin{array}{l}-0,060 \text { **** } \\
(0,018)\end{array}$ & $\begin{array}{l}-0,360 \text { *** } \\
(0,067)\end{array}$ \\
\hline Büyüklük $\left(m^{2}\right)$ & $\begin{array}{l}0,005 * * * \\
(0,000)\end{array}$ & $\begin{array}{l}0,005 * * * \\
(0,000)\end{array}$ & $\begin{array}{l}-0,003 * * \\
(0,001)\end{array}$ \\
\hline Binanın Yaş̧ & $\begin{array}{l}0,005^{* * * *} \\
(0,001)\end{array}$ & $\begin{array}{l}0,007 * * * \\
(0,001) \\
\end{array}$ & $\begin{array}{l}0,009^{*} \\
(0,005)\end{array}$ \\
\hline Doğalgaz & $\begin{array}{l}0,120 \text { **** } \\
(0,024)\end{array}$ & $\begin{array}{l}0,163 \text { *** } \\
(0,021)\end{array}$ & $\begin{array}{l}0,205 * * * \\
(0,077)\end{array}$ \\
\hline Asansör & $\begin{array}{l}0,066^{* * *} \\
(0,029)\end{array}$ & $\begin{array}{l}0,055^{* *} \\
(0,025)\end{array}$ & \begin{tabular}{|l|}
$-0,077$ \\
$(0,093)$
\end{tabular} \\
\hline Kapalı Otopark & $\begin{array}{l}0,137 * * * \\
(0,029)\end{array}$ & \begin{tabular}{|l}
0,091 *** \\
$(0,025)$
\end{tabular} & $\begin{array}{l}-0,234 * * \\
(0,092)\end{array}$ \\
\hline Site Içinde & $\begin{array}{l}-0,048^{*} \\
(0,027)\end{array}$ & \begin{tabular}{|l|}
$-0,044^{*}$ \\
$(0,023)$
\end{tabular} & $\begin{array}{l}0,055 \\
(0,085)\end{array}$ \\
\hline Dışs Isı Yalıtımı & \begin{tabular}{|l|}
0,023 \\
$(0,028)$ \\
\end{tabular} & \begin{tabular}{|l|}
0,000 \\
$(0,025)$ \\
\end{tabular} & \begin{tabular}{|l}
$-0,173^{*}$ \\
$(0,090)$ \\
\end{tabular} \\
\hline Merkeze Yakınlık & $\begin{array}{l}0,056^{*} \\
(0,030)\end{array}$ & \begin{tabular}{|l}
0,091 **** \\
$(0,026)$
\end{tabular} & $\begin{array}{l}0,221^{* * *} \\
(0,095)\end{array}$ \\
\hline Toplu Taşımaya Yakınlık & \begin{tabular}{|l|}
$-0,025$ \\
$(0,031)$ \\
\end{tabular} & \begin{tabular}{|l|}
$-0,044$ \\
$(0,027)$ \\
\end{tabular} & $\begin{array}{l}-0,138 \\
(0,100) \\
\end{array}$ \\
\hline$F$ İstatistiği & $63,576^{* * * *}$ & $52,327 * * *$ & $20,507 * * *$ \\
\hline$R^{2}$ (Düzeltilmişs) & 0,282 & 0,244 & 0,109 \\
\hline
\end{tabular}

Not: Parantez içerisindeki sayılar standart hata değerleridir. *\%10,**\%5,***\%1 düzeyinde katsayıların anlamlı olduğunu ifade etmektedir.

İkinci sütunda kiranın doğal logaritması aynı değişkenlerle tahmin edilmiştir. Konutun büyüklüğü, binanın yaşı, doğalgaz imkânı, asansör, kapalı otopark ve merkeze yakınlık kiraları arttırırken, oda sayısı ve site içerisinde olması kiraların düşmesine neden olmaktadır. Dış 1sı yalıtımı ve toplu taşımaya yakınlık ile kira arasında ise anlamlı bir ilişki ortaya çıkmamaktadır. Oda sayısının etkisi çok düşük düzeyde negatif ilişki ile ortaya çıkarken, konutun büyüklüğü belirgin olarak kirayı yukarıya çekmektedir. Örneğin, aynı özelliklere sahip $100 \mathrm{~m}^{2}$ 'lik bir konutun kirası 500.-TL, ise $150 \mathrm{~m}^{2}$ 'lik muadil bir konutun kirası 625.-TL'dir. 
Üçüncü sütunda ise kapitalizasyon oranı aynı değişkenlerle tahmin edilmektedir. Asansörün varlığı, site içerisinde olması ve toplu taşımaya yakınlık kapitalizasyon oranını etkilememektedir. Oda sayısı, konutun büyüklüğü, kapalı otoparkın varlığı ve dış 1sı yalıtımı kapitalizasyon oranını negatif etkilemektedir. Diğer yandan binanın yaşı, doğalgaz imkânı ve merkeze yakınlık kapitalizasyon oranı üzerinde pozitif etki yaratmaktadır ${ }^{1}$.

Tablo: 5

Konuta Yapılan Harcamanın Geri dönüş Süresi (Yıl)

\begin{tabular}{|c|c|}
\hline Değişken & Geri Dönüşüm Süresi (Yıl) \\
\hline Ortalama & 18,0 \\
\hline Oda Saylsı (1 oda fazlast) & 19,2 \\
\hline Büyüklük (50 $\mathrm{m}^{2}$ fazlası) & 18,5 \\
\hline Binanın Yaşı (1 yıl fazlası) & 17,9 \\
\hline Doğalgaz & 17,3 \\
\hline Kapalı Otopark & 18,7 \\
\hline Dıș Isı Yalıtımı & 18,5 \\
\hline Merkeze Yakınlık & 17,3 \\
\hline
\end{tabular}

Bulgulara göre, konut fiyatları ve kiraların aynı oranda artması halinde, ortalama kapitalizasyon oranı 5,57 olduğuna göre, bir konuta harcanan TL tutarı yaklaşık olarak 18 yılda geri dönmektedir (ilk satır). Oda sayısının 1 artması, geri dönüşü 1,2 yıl geciktirmektedir. Evin büyüklüğündeki $50 \mathrm{~m}^{2}$ 'lik artış geri dönüşü 6 ay uzatmaktadır. Kapalı otopark ve dış 1sı yalıtımının varlı̆̆ da benzer bir etki yaratmaktadır. Diğer yandan binanın yaşı arttıkça geri dönüş süresi kısalmaktadır. Doğalgaz ve merkeze yakınlık da benzer bir etki yaratmaktadır. Burada dikkat edilmesi gereken konu, konut fiyatları ile kira bedellerinin aynı oranda artacağının varsayılmasıdır. Eski konutların daha fazla bakım ve onarım harcaması gerektirmesi ve yeni evlerin bulunduğu konuma göre daha fazla değer artış kazancı sağlayacağı varsayılabilir. Zaman itibariyle ortaya çıkabilecek değişimlerin ancak zaman serileri ile analiz edilebilmesi mümkündür.

\section{Sonuç}

Konutun alış maliyeti ile kazancı arasındaki ilişki, barınma veya yatırım amacıyla alınmış olsun, karar vermede önemli bir göstergedir. Bu ilişkide önemli göstergelerden birisi olan kapitalizasyon oranının düşük olması, yani diğer koşullar veri iken kira geliri ile satın alma maliyetinin geri dönüşünün uzun zaman alması, konut talebinde caydırıcı etki yaratır. Diğer yandan bu geri dönüş süresinin kısalması konut talebini destekleyici etki yaratacaktır. Kapitalizasyon oranını etkileyen makro değişkenler (faiz oranı, konjonktür, alternatif

1 Kat Sayısı da bütün tahminlere dâhil edilmiş, ancak anlamlı çıkmamıştır. Ayrıca asansörü olmayan yüksek katlı konutların fiyat ve kiraları negatif etkilediğine ilişkin bazı bulgular mevcut olmakla beraber istatistiksel olarak anlamlı çıkmamıştır. 
yatırım araçlarının getirisi vb.) yanında, konutun özellikleri de etkili olabilir. Bu makalede konutun içsel özellikleri test edilmiştir.

Kapitalizasyon oranı oda sayısı, konutun büyüklüğü, kapalı otoparkın varlığı ve dış 1sı yalıtımından olumsuz etkilenirken, binanın yaşı, doğalgaz imkânı ve merkeze yakınlıktan olumlu yönde etkilenmektedir. Asansörün varlığı, site içerisinde olması ve toplu taşımaya yakınlık ise kapitalizasyon oranını etkilememektedir. Bulgulara göre, konut fiyatları ve kiraların aynı oranda artması halinde, bir konuta harcanan para tutarı yaklaşık olarak 18 yılda geri dönmektedir. Oda sayısının 1 artması, geri dönüşü 1,2 y1l geciktirmektedir. Evin büyüklüğündeki $50 \mathrm{~m}^{2}$ 'lik artış geri dönüşü 6 ay uzatmaktadır. Diğer yandan binanın yaşı arttıkça geri dönüş süresi kısalmaktadır.

Burada yapılan analiz statik bir karaktere sahiptir ve zaman içerisinde konutların değeri ve kirasına ilişkin değişimler dikkate alınamamaktadır. Burada dikkat edilmesi gereken konu, konut fiyatları ile kira bedellerinin aynı oranda artacağının varsayılmasıdır. Eski konutların daha fazla bakım ve onarım harcaması gerektirmesi ve yeni evlerin bulunduğu konuma göre daha fazla değer artış kazancı sağlayacağ 1 varsayılabilir. Zaman itibariyle ortaya çıkabilecek değişimlerin ancak zaman serileri ile analiz edilebilmesi mümkündür. $\mathrm{Bu}$ yüzden, konutların içsel özelliklerinin etkisini ölçen bu çerçevenin, verilerin uygun olması halinde dinamik bir analizle tamamlanması gerekir.

\section{Kaynakça}

Altınırmak, S. \& A. Afşar \& C. Hacıköylü (2013), Emlak, Finans ve Emlak Değerleme, Eskişehir, Anadolu Üniversitesi Yayını No: 2773, Açıköğretim Fakültesi Yayını No: 1731.

Ambrose, B.W. \& H.O. Nourse (1993), "Factors Influencing Capitalization Rates", Journal of Real Estate Research, 8 (2), 221-237.

An, X. \& Y. Deng (2009), “A Structural Model For Capitalization Rate”, A Research Report to Real Estate Research Institute (RERI), 1-41.

Ayan, E. (2010), "Gayrimenkul Değerlemesinde Gelir İndirgeme Yaklaşımı ve Yaklaşımın Türkiye Koşullarında Uygulanabilirliği (Kocaeli Uygulaması)", Ç.Ü. Sosyal Bilimler Enstitüsü Dergisi, 19(1), 382-397.

Bekmez, S. \& A. Özpolat (2013), “Türkiye'de Konut Talebinin Belirleyenleri: Dinamik Bir Analiz”, TiSK Akademi, (II), 170-187.

Berberoğlu, M. (2009), "Mortgage-İpotekli Konut Finansman-Sistemi ve Bu Sistemin Türkiye'de Uygulanabilirliği', International Journal of Economic and Administrative Studies, 1 (2), $119-146$.

Dettling, L.J. \& M.S. Kearney (2014), "House Prices And Birth Rates: The Impact of The Real Estate Market On The Decision To Have A Baby", Journal of Public Economics, 110 (2), 82-100.

Deloitte (2010), Türkiye Cumhuriyeti Başbakanlı Yatırım Destek ve Tanttım Ajansı Türkiye Gayrimenkul Sektörü Raporu.

Emlak Konut Gayrimenkul Yatırım Ortaklığı (2012), Gayrimenkul Değerleme Raporları. 
Emlak Konut Gayrimenkul Yatırım Ortaklığı (2014), Gayrimenkul Değerleme Raporlarl.

EVA Gayrimenkul Değerleme Danışmanlık (2011), Akmerkez Gayrimenkul Yatırım Ortaklığ , Akmerkez Değerleme Raporu.

Evans, R.D. (1990), “A Transfer Function Analysis of Real Estate Capitalization Rates”, Journal of Real Estate Research, 5 (3), 371-379.

Follain, J.R. \& E. Jimenez (1985), "Estimating the Demand for Housing Characteristics: A Survey and Critique", Regional Science and Urban Economics, 15, 77-107.

Froland, C. (1987), "What Determines Cap Rates on Real Estate", Journal of Portfolio Management, $13,77-83$.

Hendershott P.H. \& B. Turner (1999), “Capitalization Rates and Capitalization Effects of Below Market Financing”, Journal of Property Research, 16(2), 109-122.

IMF (2004), "Three Current Policy Issues: The Global House Price Boom", IMF World Economic And Financial Surveys, World Economic Outlook The Global Demographic Transition Chapter II.

Jud, G.D. \& D.T. Winkler (1995), “The Capitalization Rate of Commercial Properties and Market Returns", Journal of Real Estate Research, 10 (5), 509-518.

Kenneth Y.C. \& M. Greenstone (1998), "Does Air Quality Matter Evidence From The Housing Market", NBER Working Paper Series, Working Paper 6826.

Liu, C.H. \& D. Hartzell \& W. Greig \& T. Grissom (1990), "The Integration of The Real Estate Market And The Stock Market: Some Preliminary Evidence”, Journal of Real Estate Finance and Economics, 3(3), 261-282.

McGrath, K.M. (2013), "The Effects of Eco-Certification on Office Properties: A Cap Rates-Based Analysis", Journal of Property Research, 30(4), 345-365.

McGreal S. \& P. Taltavull de La Paz (2012), "An Analysis of Factors influencing Accuracy in The Valuation of Residential Properties in Spain”, Journal of Property Research, 29 (1) 1-24.

Sun, C. \& S. Zheng \& R. Han (2010), "The Effects of Subway Construction on Housing Premium: A Micro-Data Analysis in Chengdu's Housing Market”, Institute of Real Estate Studies, Tsinghua University, Beijing, P.R. Chi, Mimeo.

Özsoy, O. \& S. Şahin (2009), "Housing Price Determinants in Istanbul, Turkey An Application of the Classification and Regression Tree Model", International Journal of Housing Markets and Analysis, Vol. 2 No. 2, 167-178.

Öztürk, N. \& E. Fitöz (2009), "Türkiye'de Konut Piyasasının Belirleyicileri: Ampirik Bir Uygulama”, ZKÜ Sosyal Bilimler Dergisi, 5 (10), 21-46. 